\title{
The Impact of Corporate Income Tax on R\&D of Multinational Entities: An Impact Analysis of Separate Taxation and CCCTB
}

\author{
Hulya Celebi - Sabina Hodžić
}

\begin{abstract}
:
The significant contribution of $R \& D$ to economic development and sustainability has been shown by various studies. Therefore, governments offer different fiscal instruments to attract $\mathrm{R} \& \mathrm{D}$, especially regarding multinational entities (MNEs). One of the fiscal instruments are tax incentives for R\&D. Furthermore, the EU has been working on the switch from Separate Taxation (ST) to Common Consolidated Corporate Tax Base (CCCTB) for longer than a decade, which will lead to harmonized R\&D tax allowances, however without harmonizing the tax rates. Hence, this study aims at analyzing how ST and CCCTB impact the location of MNEs' R\&D activities, tax burden and countries' tax revenue through a case study. The results show that, under ST, tax jurisdictions can stimulate MNEs' R\&D activities by means of attractive tax allowances and lower tax rates. Especially for high-tax countries, the tax allowances represent an important tool for attracting R\&D activities. However, under CCCTB, the location of R\&D activities additionally depends on the Formula Apportionment (FA) factors of the tax base, where the countries cannot exert a direct influence. Hence, the reduction of tax rates remains the only tool left to Member States, which can lead to revenue loss on the whole. Furthermore, the FA of the tax base under CCCTB mitigates the impact of any dislocation of R\&D to a low-tax country, which, under ST, leads to larger tax savings of MNEs and its impact on jurisdictions' tax revenue is greater.
\end{abstract}

Key words: Corporate income tax; Tax incentives for R\&D; CCCTB; Separate taxation.

JEL classification: $\mathrm{H} 20, \mathrm{H} 25, \mathrm{O} 23$.

\section{Introduction}

Changes in the economic environment, technology, globalization and business structures entail discussions about the appropriateness of the currently used source-based taxation principle of ST in this changed environment (see e.g. IMF, 2014). Hence, the EU has been working on changing corporate income taxation (CIT) within the EU. After working for longer than one decade, in 2011, the European Commission proposed the CCCTB, which called FA as an alternative to

Hülya Çelebi; University of Innsbruck, School of Management, Department of Accounting, Auditing and Taxation, Kalsfeld 24, 6365 Kirchberg iT, <huelya.celebi@ gmail.com>.

Sabina Hodžić; University of Rijeka, Faculty of Tourism and Hospitality Management, Department of Public Finance, Primorska 42, 51410 Opatija, Croatia, <sabinah@fthm.hr>. 


\section{Celebi, H. - Hodžić, S.: The Impact of Corporate Income Tax on R\&D of Multinational Entities: An} Impact Analysis of Separate Taxation and CCCTB.

the existing ST into question ${ }^{1}$. The objective of this proposal is to solve the corporate income taxation dilemma within the EU, which negatively impacts investments within the EU and the growth of the Single Market. This covers issues such as higher compliance and administrative costs, double taxation, nontransparency regarding tax regulations with which the European MNEs are confronted. Tax competition across the Member States is another reason for this proposal, since the existence of 28 national corporate tax regulations within the EU disadvantages every Member State as well as the EU as a whole (see e.g. Devereux et al., 2002; Genschel et al., 2008; Eggert and Haufler, 2006; Eurostat, 2014; Huizinga and Laeven, 2008).

CCCTB is a system of common rules for computing the tax base of corporations that are tax residents in the EU and in EU-located branches of third-country companies. Besides switching from ST to FA, the CCCTB proposal also covers consolidation of taxable income and offsetting of cross-border losses, however without tax rate harmonization (European Commission, 2011). This means each Member State will still have the authority to determine its tax rate. The European Commission $(2016 \mathrm{a} ; 2016 \mathrm{~b})$ recently left no doubts about its persistence on CCCTB's implementation. In the first proposal, the use of CCCTB was determined to be optional for MNEs, where the MNEs would have the opportunity to choose between taxation under ST or CCCTB. This optional use triggered contradicting views and study outcomes in the literature (Devereux and Loretz, 2008; Herzig and Kuhr, 2012; Hey, 2008; Mintz, 2004; Oestreicher and Koch, 2011). However, as of the latest publication, its application has been made mandatory for MNEs. Furthermore, in the latest proposal, the implementation of the CCCTB has been split into two steps: in the first step, the focus is on the harmonization of tax base regulations, after that, in the second step, the allocation of the tax base by means of FA is envisaged (European Commission 2016a, 2016b).

Moreover, on one hand, the appropriateness of CCCTB to achieve its objectives, such as reduction of administrative and compliance costs, elimination of transfer pricing, double taxation and discrimination issues, is questioned by some researchers (Fuest, 2008, Herzig and Kuhr, 2012, Roeder, 2012). On the other hand, it has been evaluated by a research group as being in line with the general

\footnotetext{
ST means that the tax base of each corporate group member is calculated and taxed according to tax regulations of its country of registration. However, FA provides for the determination of the consolidated tax base for all corporate group members based on a common set of regulations. This tax base is then allocated to each corporate group member according to the FA factors, and is subject to the tax rate of the respective resident country where each corporate group member is located (see Formula 1 in Part 2.1). Therefore, FA can lead to discrepancies in countries where the tax base is earned and taxed.
} 
principles of international taxation (Spengel et. al., 2012; Spengel and Zöllkau, 2012).

Here, the divergence from the source-based taxation principle of FA is the point of the CССТВ that has triggered the most intensive discussions in politics as well as in the field of research. The implementation of CCCTB will also entail the enlargement and increasing importance of FA in CIT practice, which has been in practice in Canada and the United States.

Regarding the appropriateness of FA for the allocation of the tax base, there are divergent results and views (for a detailed literature review see e.g. Celebi, 2013). For instance, Zagler (2009) advocates excluding assets, whereas Hellerstein and McLure (2004) approve of it as the sole appropriate allocation factor. Another point is the exclusion of intangible assets, seen as reasonable because of their manipulability (Sørensen, 2004; Mueller, 2010). However, the revenue generated by intangible assets is taken into account when calculating the tax base. In contrast, payroll is taken into consideration when allocating the tax base, even though it decreases the tax base. This asymmetrical consideration of revenues and expenses makes the accurateness of the allocation factors questionable (Altshuler and Gruber, 2011; Hines, 2010). This asymmetry in the tax base determination and allocation can also disadvantage R\&D investments within the EU, as they have mostly intangibles as their output. Consequently, any distortions caused by the taxation of R\&D activities can impact productivity, growth or employment in Member States in the long run because of the impact of $R \& D$ on innovation (Hodžić, 2013). Furthermore, tax incentives are the only way the government can affect the amount of R\&D undertaken and its economic impact (Griffith et al., 1995; Hall and Van Reenen 2000). Here, McKenzie (2008) shows that the tax treatment of R\&D is often quite complex across jurisdictions. Zee et al. (2002) examined the objectives, cost effectiveness and transparency of implementing tax incentives in developing countries. They found that the use of tax incentives should be limited to the rectification of market failures and that the preferred form of tax incentives are those that provide for fast recovery of investment costs.

Due to these divergent results related to tax allowances (or incentives) as well as ST and FA, the question arises as: "How do the CIT systems, ST vs. CCCTB, impact the R\&D activities of MNEs?" Here, the availability of data about R\&D is limited to the monetary amount of R\&D expenditures, which, in some countries, is not available at all. Hence, the firm-level data regarding R\&D activities, such as assets, payroll and the number of employees in R\&D departments, are not available either, which precludes conducting an empirical study. Therefore, the case study remains as the only methodological tool able to answer the research question above. This case study investigates the impact of CIT on MNEs' R\&D activities as well as on MNEs' tax burden, while taking R\&D incentives as well as 
Celebi, H. - Hodžić, S.: The Impact of Corporate Income Tax on R\&D of Multinational Entities: An Impact Analysis of Separate Taxation and CCCTB.

the dislocation of R\&D activities to low-tax countries into account. The outcomes of the study under the scenarios and assumptions made related to MNEs' financial information and $R \& D$ tax incentives, show that higher $R \& D$ tax incentives attract the location of MNEs' R\&D activities under ST. This shows that jurisdictions can directly impact the R\&D of MNEs by means of favorable incentives and tax rates. In contrast, CCCTB decreases the direct influence of Member States on R\&D by means of harmonized tax allowances for all Member States. Here, in case of high tax rate differences across the Member States, CCCTB makes the location of R\&D in low-tax countries more favorable, which could strengthen the rate-cutting trend within the EU in the long run.

\section{Case Study}

As mentioned above, because of the non-availability of data regarding the $R \& D$ departments of MNEs, the impact analysis of ST and CCCTB is based on a case study. This study focuses on the taxation of an MNE's income, with the parent company resident in Country A and a subsidiary resident in Country B. Country A is assumed to be a Member State of the EU, whereas Country B could be a Member State or a non-EU country.

The aim of this study is to analyze the impact of CIT on the location decision of an MNE for its subsidiary as well as its R\&D activities. The parent company makes the decision to locate its subsidiary either in an EU Member State or in a third country. It is assumed that both alternative countries do not exhibit any difference in tax rates, payroll or any other expenses or revenue. The only difference between both countries is the location, namely inside the EU or not. The comparison of ST and CCCTB enables the answering of the research questions from two different perspectives:

- What is the impact of a switch to CCCTB on R\&D for Member States?

- How does ST impact R\&D investment in a third country when European Member States apply the CCCTB?

The impact of ST and CCCTB is analyzed under three different scenarios, namely 1) no $R \& D$ tax allowances are granted, 2) different $R \& D$ allowances are granted, and 3) the MNE locates all its R\&D activities in its subsidiary.

\subsection{Case study setting}

The scenarios for the analysis of ST and CCCTB are based on the financial information of the parent company and the subsidiary as shown in Table 1 below. Here, it is assumed that the only difference between the parent company and its subsidiary is related to their R\&D; everything else is equal. Furthermore, for the determination of tax rates, tax rates that represent the average rates across the EU Member States are chosen, although tax rates vary between $10 \%$ and $33 \%$ within 
the EU. The purpose of making these two assumptions is not to blur the impact of both tax systems caused by differences in sales, assets as well as high tax rates between both companies and therefore to eliminate any impact resulting from these differences on results in general.

Tab. 1 Baseline Scenario

\begin{tabular}{lllllll}
\hline Country & $\begin{array}{l}\text { Sales in } \\
\text { Mio. } €\end{array}$ & $\begin{array}{l}\text { Number of } \\
\text { employees }\end{array}$ & $\begin{array}{l}\text { Payroll in } \\
\text { Mio. } €\end{array}$ & $\begin{array}{l}\text { Assets in } \\
\text { Mio. } €\end{array}$ & $\begin{array}{l}\text { Tax base in } \\
\text { Mio. } €\end{array}$ & CIT rate \\
\hline A & 1,000 & 600 & 60 & 1,500 & 150 & $25 \%$ \\
B & 1,000 & 600 & 60 & 1,500 & 175 & $20 \%$ \\
\hline
\end{tabular}

Source: Authors' calculation.

It is assumed that the MNE plans to invest in R\&D in each entity, for which tax allowances are granted, as shown in the following table. It is important to mention that the term assets hereafter refers to tangible assets:

\section{Tab. 2 R\&D Scenario}

\begin{tabular}{lll}
\hline & Country A & Country B \\
\hline Annual R\&D Expenses in Mio. $€$ & 40 & 15 \\
Number of employees & 150 & 50 \\
Payroll in Mio. $€$ & 15 & 5 \\
Assets in Mio. $€$ & 400 & 150 \\
Tax allowances $^{2}$ & $25 \%$ & $100 \%$ \\
\hline
\end{tabular}

Source: Authors' calculation.

\subsection{Scenario 1 - without taking $R \& D$ into account}

This scenario analyzes the impact of CCCTB and ST under the assumption that no tax allowances are granted for R\&D activities and investments of MNEs.

In the case of ST, it is assumed that the subsidiary is located in a third country or the MNE does not fulfill the requirements for the CCCTB (Art. 5, European Commission, 2016a). Based on the scenario shown in Table 1, the following is given for the CIT burden and net income for the MNE:

2 In practice, for instance Austria grants currently tax allowance of $25 \%$ for R\&D expenditures, and Croatia of $100 \%$, respectively. 
Celebi, H. - Hodžić, S.: The Impact of Corporate Income Tax on R\&D of Multinational Entities: An Impact Analysis of Separate Taxation and CCCTB.

Tab. 3 Results ST under Scenario 1

\begin{tabular}{llll}
\hline Country & $\begin{array}{l}\text { Tax base in } \\
\text { Mio. } €\end{array}$ & $\begin{array}{l}\text { CIT burden } \\
\text { in Mio. } €\end{array}$ & $\begin{array}{l}\text { Net income } \\
\text { in Mio. } €\end{array}$ \\
\hline A & 150 & 37,5 & 112,5 \\
B & 175 & 35 & 140 \\
\hline
\end{tabular}

Source: Authors' calculation.

As mentioned above, taxation under FA first requires the allocation of the MNE's tax base to each of its entities. The formula for FA within the framework of the CCCTB is based on the Massachusetts formula, e.g. the tax base share of group member $\mathrm{A}$ is apportioned in relation to the sum of all the group members (Group) as shown in the following (European Commission, 2011):

Share $\mathrm{A}=$
$\left(\frac{1}{3} \frac{\text { Assets }^{\mathrm{A}}}{\text { Assets }^{\text {Group }}}+\frac{1}{3} \frac{\text { Sales }^{\mathrm{A}}}{\text { Sales }^{\text {Group }}}+\frac{1}{3}\left(\frac{1}{2} \frac{\text { Payroll }^{\mathrm{A}}}{\text { Payroll }^{\text {Group }}}+\frac{1}{2} \frac{\text { Number of Employees }^{\mathrm{A}}}{\text { Number of Employees }^{\text {Group }}}\right)\right)$ Consolidated Tax Base $_{\text {Group }}$

Based on this formula, the FA of the MNE's parent company A is given as in the following formula and table:

$$
\text { Share } A=\left(\frac{1}{3} \times \frac{1,500}{3,000}+\frac{1}{3} \times \frac{1,000}{2,000}+\frac{1}{3} \times\left(\frac{1}{2} \times \frac{60}{120}+\frac{1}{2} \times \frac{600}{1,200}\right)\right)=0.5
$$

\section{Tab. 4 FA - Scenario 1}

\begin{tabular}{llllll}
\hline Country & Sales & Number of employees & Payroll & Assets & Total \\
\hline A & 0.167 & 0.083 & 0.083 & 0.167 & 0.5 \\
B & 0.167 & 0.083 & 0.083 & 0.167 & 0.5 \\
\hline
\end{tabular}

Source: Authors' calculation.

If the parent company locates its subsidiary in an EU Member State and qualifies for CCCTB, then the allocation of the tax base occurs based on FA, is as shown in the following:

\section{Tab. 5 Results CCCTB under Scenario 1}

\begin{tabular}{|c|c|c|c|c|c|c|c|c|}
\hline & $\begin{array}{l}\text { Sales in } \\
\text { Mio. } €\end{array}$ & $\begin{array}{l}\text { Number of } \\
\text { employees }\end{array}$ & $\begin{array}{l}\text { Payroll in } \\
\text { Mio. } €\end{array}$ & $\begin{array}{l}\text { Assets in } \\
\text { Mio. } €\end{array}$ & $\begin{array}{l}\text { Tax base in } \\
\text { Mio. } €\end{array}$ & $\begin{array}{l}\text { FA- } \\
\text { Factor }\end{array}$ & $\begin{array}{l}\text { CIT } \\
\text { burden }\end{array}$ & $\begin{array}{l}\text { Net } \\
\text { income }\end{array}$ \\
\hline A & 1,000 & 600 & 60 & 1,500 & 150 & 0.5 & 40.63 & 109.38 \\
\hline B & 1,000 & 600 & 60 & 1,500 & 175 & 0.5 & 32.50 & 142.50 \\
\hline
\end{tabular}

Source: Authors' calculation. 
Here, the calculation of net income, for example of a subsidiary in $\mathrm{B}$, is formulated as in the following:

$$
\text { Tax Burden B }=\left(\frac{1}{3} \times \frac{1,500}{3,000}+\frac{1}{3} \times \frac{1,000}{2,000}+\frac{1}{3} \times\left(\frac{1}{2} \times \frac{60}{120}+\frac{1}{2} \times \frac{600}{1,200}\right)\right) \times 325 \times 0.2=\underline{\underline{32.50}}
$$

Net IncomeB $=175-32.50=\underline{\underline{142.50}}$

Because the taxation is based on the allocation factors, half of the total tax base is taxed in Country A, even though it exhibits a lower tax base than the subsidiary in B. Hence, the use of FA leads to higher taxation in A and lower taxation in B compared to ST.

\subsection{Scenario 2 - taking $R \& D$ into account}

When taking an $R \& D$ allowance given as a percentage of $R \& D$ expenditures in each country into account, ST leads to the following results:

\section{Tab. 6 Results ST under Scenario 2}

\begin{tabular}{|c|c|c|c|c|c|c|}
\hline & $\begin{array}{l}\text { Tax base in } \\
\text { Mio. € }\end{array}$ & $\begin{array}{l}\text { R\&D } \\
\text { Allowance } \\
\text { in \% }\end{array}$ & $\begin{array}{l}\text { R\&D } \\
\text { Allowance in } \\
\text { Mio. } €\end{array}$ & $\begin{array}{l}\text { Tax base net } \\
\text { of } R \& D A . \text { in } \\
\text { Mio. } €\end{array}$ & $\begin{array}{l}\text { CIT burden } \\
\text { in Mio. } €\end{array}$ & $\begin{array}{l}\text { Net } \\
\text { income in } \\
\text { Mio. } €\end{array}$ \\
\hline A & 150 & $25 \%$ & 10 & 140 & 35 & 115 \\
\hline B & 175 & $100 \%$ & 15 & 160 & 32 & 143 \\
\hline
\end{tabular}

Source: Authors' calculation.

Taking the R\&D allowances in each country into account decreases the tax burden. Because of the lower allowance, the tax base decreases by $25 \%$ of the total research expenses in Country A, whereas an allowance of $100 \%$ provides for a double deduction of the research expenses from the tax base in Country B.

In contrast, the envisaged CCCTB provides for a $50 \%$ allowance of the R\&D expenses of up to 20 million euros, and $25 \%$ for the exceeding amount.

\section{Tab. 7 Results CCCTB under Scenario 2}

\begin{tabular}{|c|c|c|c|c|c|c|c|c|}
\hline & $\begin{array}{l}\text { Sales in } \\
\text { Mio. } €\end{array}$ & $\begin{array}{l}\text { Number of } \\
\text { employees }\end{array}$ & $\begin{array}{l}\text { Payroll in } \\
\text { Mio. } €\end{array}$ & $\begin{array}{l}\text { Assets in } \\
\text { Mio. } €\end{array}$ & $\begin{array}{l}\text { Tax base in } \\
\text { Mio. } €\end{array}$ & $\begin{array}{l}\text { FA- } \\
\text { Factor }\end{array}$ & $\begin{array}{l}\text { CIT } \\
\text { burden }\end{array}$ & $\begin{array}{l}\text { Net } \\
\text { income }\end{array}$ \\
\hline A & 1,000 & 600 & 60 & 1,500 & 150 & 0.5 & 38.28 & 111.72 \\
\hline B & 1,000 & 600 & 60 & 1,500 & 175 & 0.5 & 30.63 & 144.38 \\
\hline
\end{tabular}

Tax Base pre-R\&D Allowance 325

Super deduction of R\&D (25\%/50\%) 18.75

Tax Base net of R\&D Allowance 306.25

Source: Authors' calculation. 
Celebi, H. - Hodžić, S.: The Impact of Corporate Income Tax on R\&D of Multinational Entities: An Impact Analysis of Separate Taxation and CCCTB.

As shown in Table 7 above, CCCTB leads to a higher tax burden than under ST. This is caused by two factors. Firstly, the tax base allocated to A under FA is higher than the tax base it realized. Secondly, the limitation of the R\&D allowance to $25 \%$ and $50 \%$ decreases the total allowance of 25 million euros under ST to 18.75 million euros under CCCTB. Both factors lead to an increase in the total CIT burden by $2.85 \%$. An increase in the tax rate difference between Countries A and $\mathrm{B}$ as well as in allocation factors in A would raise the difference between ST and CCCTB to a higher amount (see Table 10, Appendices 1 and 2).

\subsection{Scenario 3 - Dislocation of R\&D}

This section aims at analyzing the impact of ST and CCCTB when the parent company decides to locate all planned $R \& D$ activities in $\mathrm{B}^{3}$, where the allowance is higher; however the deduction of the R\&D expense occurs at a lower CIT rate.

\section{Tab. 8 Results ST under Scenario 3}

\begin{tabular}{lllllll}
\hline & $\begin{array}{l}\text { Tax base in } \\
\text { Mio. } €\end{array}$ & $\begin{array}{l}\text { R\&D } \\
\text { Allowance } \\
\text { in \% }\end{array}$ & $\begin{array}{l}\text { R\&D } \\
\text { Allowance in } \\
\text { Mio. } €\end{array}$ & $\begin{array}{l}\text { Tax base net } \\
\text { of R\&D A. in } \\
\text { Mio. } €\end{array}$ & $\begin{array}{l}\text { CIT burden } \\
\text { in Mio. } €\end{array}$ & $\begin{array}{l}\text { Net } \\
\text { income in } \\
\text { Mio. } €\end{array}$ \\
\hline A & 190 & $25 \%$ & 0 & 190 & 47.5 & 142.5 \\
B & 135 & $100 \%$ & 55 & 80 & 16 & 119 \\
\hline
\end{tabular}

Source: Authors' calculation.

Because of the double deduction of the whole R\&D costs by means of a $100 \%$ allowance in B, the total tax burden decreases by 5.3\%. However, this impact is mitigated by the tax rate difference between both countries, namely the shift of $\mathrm{R} \& \mathrm{D}$ expenses from $\mathrm{A}$ to $\mathrm{B}$ increases the tax base in $\mathrm{A}$, which is subject to taxation at the higher tax rate.

In contrast, under CCCTB, as the dislocation incurs within the MNE, the total tax base and also the total tax allowance of R\&D remain unchanged. However, the location of all R\&D assets and employees in B increases FA for B and decreases it for $\mathrm{A}$, which means a higher tax base is taxed in $\mathrm{B}$ and a lower one in $\mathrm{A}$, even though the dislocation leads to a decrease in the income before tax in $\mathrm{B}$ by the amount of the R\&D expenses shifted.

As shown in the Table 9 below, the decrease in the R\&D allowance from $100 \%$ under ST to $34.1 \%$ under FA increases the total CIT burden by approx. 6.5\%. The increased allocation of the tax base to $\mathrm{B}$, i.e. taxation at a lower tax rate, mitigates this negative impact caused by the lower allowance of CCCTB. Higher tax rate

3 It is important to mention that this scenario refers to the location of all planned R\&D activities in $\mathrm{B}$ and not a dislocation of existing R\&D from $\mathrm{A}$ to $\mathrm{B}$, where Art. 22 CCCTB (European Commission, 2016a) would have to be applied. 
differences between both countries (see e.g. Appendix 1) as well as higher asset and labor intensity of the dislocated R\&D activities mitigate the negative impact of the lower allowance under CCCTB.

From the perspective of the jurisdictions, the switch from ST to CCCTB would decrease the tax revenue of A by $33 \%$.

\section{Tab. 9 Results CCCTB under Scenario 3}

\begin{tabular}{|c|c|c|c|c|c|c|c|c|}
\hline & $\begin{array}{l}\text { Sales in } \\
\text { Mio. } €\end{array}$ & $\begin{array}{l}\text { Number of } \\
\text { employees }\end{array}$ & $\begin{array}{l}\text { Payroll in } \\
\text { Mio. } €\end{array}$ & $\begin{array}{l}\text { Assets in } \\
\text { Mio. € }\end{array}$ & $\begin{array}{l}\text { Tax base } \\
\text { in } \\
\text { Mio. } €\end{array}$ & $\begin{array}{l}\text { FA- } \\
\text { Factor }\end{array}$ & $\begin{array}{l}\text { CIT } \\
\text { burden }\end{array}$ & $\begin{array}{l}\text { Net } \\
\text { income }\end{array}$ \\
\hline $\mathrm{A}$ & 1,000 & 450 & 45 & 1,100 & 190 & 0.414 & 31.69 & 158.31 \\
\hline B & 1,000 & 750 & 75 & 1,900 & 135 & 0.586 & 35.90 & 99.10 \\
\hline
\end{tabular}

Tax Base pre-R\&D Allowance

325

Super deduction of R\&D (25\%/50\%)

18.75

Tax Base net of R\&D Allowance

306.25

Source: Authors' calculation.

\section{Discussion}

As shown in Table 10 with the summary of the results, ST and CCCTB lead to differences in the tax burden and/or revenue as well as in net income. In all three scenarios, CCCTB favors the high-tax countries with higher tax revenues, which means a higher tax burden for the MNE under CCCTB. Furthermore, as shown in the last two columns, the dislocation of R\&D is beneficial for the MNE under ST; however it loses the impact under CCCTB, where the difference between the dislocation and non-dislocation (i.e. Scenarios 2 and 3) is marginal related to the total tax burden. As FA makes the tax base independent of the income earned in a country, the revenues of the low-tax country decrease, except in Scenario 3, where the increase in tax revenue of B is caused firstly by the increase in the FA factor resulting from dislocation of $R \& D$, and secondly by the decrease in $R \& D$ allowances.

Tab. 10 Summary of all scenarios ST vs. CCCTB

\begin{tabular}{lllllll}
\hline & $\begin{array}{l}\text { Scenario } \\
\text { 1 - ST }\end{array}$ & $\begin{array}{l}\text { Scenario 1 - } \\
\text { CCCTB }\end{array}$ & $\begin{array}{l}\text { Scenario } \\
\text { 2-ST }\end{array}$ & $\begin{array}{l}\text { Scenario 2 - } \\
\text { CCCTB }\end{array}$ & $\begin{array}{l}\text { Scenario } \\
\text { 3-ST }\end{array}$ & $\begin{array}{l}\text { Scenario 3 } \\
\text { - CCCTB }\end{array}$ \\
\hline Tax Burden in A & 37.5 & 40.63 & 35 & 38.28 & 47.5 & 31.69 \\
Tax Burden in B & 35 & 32.50 & 32 & 30.63 & 16 & 35.90 \\
\hline Total Tax Burden & 72.5 & 73.13 & 67 & 68.91 & 63.5 & 67.59 \\
Total Net Income & 252.50 & 251.87 & 258 & 256.09 & 261.5 & 257.41 \\
\hline
\end{tabular}


Celebi, H. - Hodžić, S.: The Impact of Corporate Income Tax on R\&D of Multinational Entities: An Impact Analysis of Separate Taxation and CCCTB.

Source: Authors' calculation.

Furthermore, when the tax rate difference between both countries increases, CCCTB makes the dislocation of R\&D to the low-tax country beneficial for the MNE. The surprising outcome is that this impact is independent of the tax allowances (see Appendices 1 to 4), which is caused by the increase of allocation factors in the low-tax country by means of FA. In contrast to this, under ST high tax rate differences accompanied with high $R \& D$ allowances in the high tax country enables the MNE to minimize its tax burden by locating all R\&D activities in the high tax country (see Appendix 5 vs. Table 10, Appendices 1-4).

\section{Conclusion}

As shown in the literature reviewed above, the impact of corporate income tax as well the $R \& D$ allowances impact the operations of multinational corporations under ST, as well as under CCCTB or FA. FA is applied in the United States and Canada, and the latest publication by the European Commission (2016a, 2016b) stated that it envisages the implementation of FA as the second step within the framework of CCCTB. This will lead to the increasing importance of FA in practice.

Here, the review of the literature reveals a gap regarding the impact of ST and CCCTB on R\&D activities. Hence, the aim of this study was to investigate the impact of CCCTB and FA on R\&D activities. Because of the non-availability of data with respect to $R \& D$ activities and departments of the corporations, the case study was the sole tool for our analysis.

The outcomes of our study demonstrate that harmonizing the tax allowance by means of CCCTB disadvantages EU Member States currently offering R\&D allowances of 50\% and higher. Third countries offering tax allowances higher than $50 \%$ possess an important tool for attracting R\&D investments.

Furthermore, the deviation from the source-based taxation principle of FA makes the tax revenue of the Member States dependent on the MNEs' FA factors located in other Member States and their tax rates, which can lead to over-taxation and a loss in tax revenue for high-tax countries under CCCTB (shown in other study settings in Eichner and Runkel, 2011; Oestreicher and Koch, 2011). Furthermore, a surprising result is that this impact is influenced by the tax rate differences between both countries, where the dislocation of the CCCTB to the low-tax country is favorable in the case of high tax rate differences between the low- and high-tax countries. This outcome stresses the increasing dependency of the Member States on each other's tax rates under CCCTB.

In summary, the situation of CIT in the EU and beyond is characterized by diverse tax systems and great differences in tax burdens on companies. This diversity causes interferences in the cross-border business of MNEs. To reduce all these tax 
obstacles in cross-border activities within the EU and beyond, the CCCTB system represents one of the measures. As shown above, the missing key element in the CCCTB system is that all the countries need to have the same corporate income tax rate, which has been intensively discussed in the field of research.

Lastly, it has to be mentioned that the use of the case study limited our impact analysis to the scenarios used. However, in order to see different patterns, we have used differences in tax rates combined with differences in tax allowances. Here, we do not make any further differences between the companies in the high- and low-tax countries, in order not to blur the outcomes with impacts resulting from other differences, besides from tax rates and allowances. In the future, the availability of real and firm-level data regarding the $R \& D$ activities of corporations will reveal further consequences of corporate income taxation on $\mathrm{R} \& \mathrm{D}$, which is unfortunately not currently the case.

\section{References}

Altshuler, R., Grubert, H., 2011. Formula Apportionment: Is it Better than the Current System and are There Better Alternatives? SSRN Electronic Journal. DOI: 10.2139/ssrn. 1844926.

Celebi, H., 2013. The CCCTB as a Proposed Solution to the Corporate Income Taxation Dilemma within the EU. EC Tax Review 22, 289-298.

Devereux, M. P., Griffith, R., Klemm, A., 2002. Corporate income tax reforms and international tax competition. Economic Policy 35, 449-495. DOI: 10.1111/1468-0327.00094.

Devereux, M. P., Loretz, S., 2008. The Effects of EU Formula Apportionment on Corporate Tax Revenues. Fiscal Studies 29, 1-33. DOI: 10.1111/j.14755890.2008.00067.x.

Eichner, T., Runkel, M., 2011. Corporate income taxation of multinationals in a general equilibrium model. Journal of Public Economics 7-8, 723-733. DOI: 10.1016/j.jpubeco.2010.12.004.

Eggert, W., Haufler, A., 2006. Company-Tax Coordination cum Tax-Rate Competition in the European Union. FinanzArchiv: Public Finance Analysis 4, 579-601. DOI: 10.1628/001522106x172706.

European Commission, 2011. Proposal for a council directive on a Common Consolidated Corporate Tax Base (CCCTB), COM (2011) 121 final, Brussels.

European Commission, 2016a. Proposal for a council directive on a Common Consolidated Corporate Tax Base (CCCTB), COM (2016) 683 final, Strasbourg.

European Commission, 2016b. Proposal for a council directive on a Common Corporate Tax Base, COM (2016) 685 final, Strasbourg. 
Celebi, H. - Hodžić, S.: The Impact of Corporate Income Tax on R\&D of Multinational Entities: An Impact Analysis of Separate Taxation and CCCTB.

Eurostat, 2014. Taxation trends in the European Union, Data for the Member States, Iceland and Norway. Eurostat statistical books, Luxembourg.

Fuest, C., 2008. The European Commission's proposal for a common consolidated corporate tax base. Oxford Review of Economic Policy 4, 720-739. DOI: 10.1093/oxrep/grn032.

Genschel, P., Kemmerling, A., Seils, E., 2008. Speeding up, down the hill: how the EU shapes corporate tax competition in the single market. TranState working papers No. 78.

Griffith, R., Sandler, D., Reenen, J., 1995. Tax Incentives for R\&D. Fiscal Studies 2, 21-44. DOI: 10.1111/j.1475-5890.1995.tb00220.x.

Hall, B., Van Reenen, J., 2000. How effective are fiscal incentives for R\&D? A review of the evidence. Research Policy 4-5, 449-469. DOI: 10.1016/s00487333(99)00085-2.

Hellerstein, W., McLure, Jr., C.E., 2004. The European Commission's Report on Company Income Taxation: What the EU Can Learn from the Experience of the US States. International Tax and Public Finance 2, 199-220. DOI: $10.1023 / b$ :itax.0000011400.45314.57.

Herzig, N., Kuhr, J. 2012. Direct taxation in the EU: the common corporate tax base as the next sub-step towards harmonization. Wroclaw Review of Law, Administration \& Economics 2, 1-12. DOI: 10.2478/wrlae-2013-0024.

Hey, J. 2008. CCCTB - Optionality. In: Common Consolidated Corporate Tax Base, Ed.: Micheal Lang et al., Linde 2008.

Hines, J. R., 2010. Income misattribution under formula apportionment. European Economic Review 1, 108-120. DOI: 10.1016/j.euroecorev.2009.08.011.

Hodžić, S., 2013. Tax incentives for research and development in Austria and Croatia: B-index. Economic Thought and Practice 2, 397-416.

Huizinga, H., Laeven, L., 2008. International profit shifting within multinationals: A multi-country perspective. Journal of Public Economics 5-6, 1164-1182. DOI: 10.1016/j.jpubeco.2007.11.002

International Monetary Fund (IMF), 2014. Spillovers in international corporate taxation. IMF Policy Papers, Washington.

Mintz, J., 2004. Corporate Tax Harmonization in Europe: It's All About Compliance. International Tax and Public Finance 2, 221-234. DOI: 10.1023/b:itax.0000011401.67566.14.

McKenzie, K. J., 2008. Measuring tax incentives for R\&D. International Tax and Public Finance 5, 563-581. DOI: 10.1007/s10797-007-9039-7.

Mueller, P., 2010. Formula Apportionment - Approaches to Reduce Tax Planning Incentives. SSRN Electronic Journal. DOI: 10.2139/ssrn.1730178. 
Oestreicher, A., Koch, R., 2011. The Revenue Consequences of Using a Common Consolidated Corporate Tax Base to Determine Taxable Income in the EU Member States. FinanzArchiv: Public Finance Analysis 1, 64-102. DOI: $10.1628 / 001522111 \times 574191$.

Roeder, E., 2012. Proposal for an Enhanced CCTB as Alternative to a CCCTB with Formulary Apportionment. SSRN Electronic Journal. DOI: $10.2139 /$ ssrn.2012640.

Sørensen, P. B., 2004. Company Tax Reform in the European Union. International Tax and Public Finance 1, 91-115. DOI: 10.1023/b:itax.0000004778.63592.96.

Spengel, C., Ortmann-Babel, M., Zinn, B., Matenaer, S., 2012. A common corporate tax base for Europe: An impact assessment of the draft council directive on a CC(C)TB. Working Paper No. 12-039, ZEW Discussion Papers.

Spengel, C., Zöllkau, Y. 2012. Common Corporate Tax Base (CC (C) TB) and determination of taxable income: An international comparison. Springer Science $\&$ Business Media.

Zee, H. H., Stotsky, J. G., Ley, E., 2002. Tax Incentives for Business Investment: A Primer for Policy Makers in Developing Countries. World Development 9, 1497-1516. DOI: 10.1016/s0305-750x(02)00050-5.

Zagler, M., 2009. The EU CCCTB proposal. A critical appraisal. Discussion Papers SFB International Tax Coordination No. 31, SFB International Tax Coordination, WU Vienna University of Economics and Business, Vienna. 
Celebi, H. - Hodžić, S.: The Impact of Corporate Income Tax on R\&D of Multinational Entities: An Impact Analysis of Separate Taxation and CCCTB.

Appendix 1: Tax rate in $A=33 \%, B=20 \%$; $R \& D$ allowance in $A=25 \%$, $B=100 \%$

\begin{tabular}{lllllll}
\hline & $\begin{array}{l}\text { Scenario } \\
\text { 1 - ST }\end{array}$ & $\begin{array}{l}\text { Scenario 1 } \\
\text { - CCCTB }\end{array}$ & $\begin{array}{l}\text { Scenario } \\
\text { 2 - ST }\end{array}$ & $\begin{array}{l}\text { Scenario 2 } \\
\text { - CCCTB }\end{array}$ & $\begin{array}{l}\text { Scenario } \\
\text { 3-ST }\end{array}$ & $\begin{array}{l}\text { Scenario 3 } \\
\text { - CCCTB }\end{array}$ \\
\hline Tax Burden in A & 49,50 & 53,63 & 46,20 & 50,53 & 62,70 & 41,83 \\
Tax Burden in B & 35,00 & 32,50 & 32,00 & 30,63 & 16,00 & 35,90 \\
\hline \multirow{2}{*}{ Total Tax Burden } & 84,50 & 86,13 & 78,20 & 81,16 & 78,70 & 77,73 \\
Total Net Income & 240,50 & 238,88 & 246,80 & 243,84 & 246,30 & 247,27 \\
\hline
\end{tabular}

Source: Authors' calculation.

Appendix 2: Tax rate in $A=33 \%, B=10 \%$; $\& D$ allowance in $A=25 \%$, $B=100 \%$

\begin{tabular}{lllllll}
\hline & $\begin{array}{l}\text { Scenario } \\
\text { 1 - ST }\end{array}$ & $\begin{array}{l}\text { Scenario 1 } \\
\text { - CCCTB }\end{array}$ & $\begin{array}{l}\text { Scenario 2 } \\
\text { - ST }\end{array}$ & $\begin{array}{l}\text { Scenario 2 } \\
\text { - CCCTB }\end{array}$ & $\begin{array}{l}\text { Scenario } \\
\text { 3- ST }\end{array}$ & $\begin{array}{l}\text { Scenario 3 } \\
\text { - CCCTB }\end{array}$ \\
\hline Tax Burden in A & 49,50 & 53,63 & 46,20 & 50,53 & 62,70 & 41,83 \\
Tax Burden in B & 17,50 & 16,25 & 17,13 & 15,31 & 12,13 & 17,95 \\
\hline Total Tax Burden & 67,00 & 69,88 & 63,33 & 65,84 & 74,83 & 59,78 \\
Total Net Income & 258,00 & 255,13 & 261,68 & 259,16 & 250,18 & 265,22 \\
\hline
\end{tabular}

Source: Authors' calculation.

Appendix 3: Tax rate in $A=33 \%, B=10 \% ; R \& D$ allowance in $A=25 \%$, $B=25 \%$

\begin{tabular}{lllllll}
\hline & $\begin{array}{l}\text { Scenario } \\
\text { 1 - ST }\end{array}$ & $\begin{array}{l}\text { Scenario 1 } \\
\text { - CCCTB }\end{array}$ & $\begin{array}{l}\text { Scenario } \\
\text { 2 - ST }\end{array}$ & $\begin{array}{l}\text { Scenario 2 } \\
\text { - CCCTB }\end{array}$ & $\begin{array}{l}\text { Scenario } \\
\text { 3- ST }\end{array}$ & $\begin{array}{l}\text { Scenario 3 } \\
\text { - CCCTB }\end{array}$ \\
\hline Tax Burden in A & 49,50 & 53,63 & 46,20 & 50,53 & 62,70 & 41,83 \\
Tax Burden in B & 17,50 & 16,25 & 17,13 & 15,31 & 12,13 & 17,95 \\
\hline Total Tax Burden & 67,00 & 69,88 & 63,33 & 65,84 & 74,83 & 59,78 \\
Total Net Income & 258,00 & 255,13 & 261,68 & 259,16 & 250,18 & 265,22 \\
\hline
\end{tabular}

Source: Authors' calculation. 
Appendix 4: Tax rate in $A=33 \%, B=10 \%$; $R \& D$ allowance in $A=100 \%$, $B=25 \%$

\begin{tabular}{lllllll}
\hline & $\begin{array}{l}\text { Scenario } \\
\text { 1 - ST }\end{array}$ & $\begin{array}{l}\text { Scenario 1 } \\
\text { - CCCTB }\end{array}$ & $\begin{array}{l}\text { Scenario } \\
\text { 2 - ST }\end{array}$ & $\begin{array}{l}\text { Scenario 2 } \\
\text { - CCCTB }\end{array}$ & $\begin{array}{l}\text { Scenario } \\
\text { 3- ST }\end{array}$ & $\begin{array}{l}\text { Scenario 3 } \\
\text { - CCCTB }\end{array}$ \\
\hline Tax Burden in A & 49,50 & 53,63 & 36,30 & 50,53 & 62,70 & 41,83 \\
Tax Burden in B & 17,50 & 16,25 & 17,13 & 15,31 & 12,13 & 17,95 \\
\hline Total Tax Burden & 67,00 & 69,88 & 53,43 & 65,84 & 74,83 & 59,78 \\
Total Net Income & 258,00 & 255,13 & 271,58 & 259,16 & 250,18 & 265,22 \\
\hline
\end{tabular}

Source: Authors' calculation.

Appendix 5: Tax rate in $A=33 \%, B=10 \%$; $R \& D$ allowance in $A=100 \%$, $\mathrm{B}=\mathbf{2 5 \%}$

\begin{tabular}{lllllll}
\hline & $\begin{array}{l}\text { Scenario } \\
\text { 1 - ST }\end{array}$ & $\begin{array}{l}\text { Scenario 1 } \\
\text { - CCCTB }\end{array}$ & $\begin{array}{l}\text { Scenario } \\
\text { 2-ST }\end{array}$ & $\begin{array}{l}\text { Scenario 2 } \\
\text { - CCCTB }\end{array}$ & $\begin{array}{l}\text { Scenario } \\
\text { 3- ST }\end{array}$ & $\begin{array}{l}\text { Scenario 3 } \\
\text { - CCCTB }\end{array}$ \\
\hline Tax Burden in A & 49,50 & 53,63 & 36,30 & 50,53 & 44,55 & 53,62 \\
Tax Burden in B & 17,50 & 16,25 & 17,13 & 15,31 & 13,50 & 14,38 \\
\hline Total Tax Burden & 67,00 & 69,88 & 53,43 & 65,84 & 58,05 & 68,00 \\
Total Net Income & 258,00 & 255,13 & 271,58 & 259,16 & 266,95 & 257,00 \\
\hline
\end{tabular}

Source: Authors' calculation.

Here, Scenario 3 assumes the dislocation of the R\&D activities to high-tax country A because of the higher R\&D allowances. 
